\title{
HUBUNGAN INTENSITAS INFORMASI KEBOGAAN MELAUI MEDIA CETAK DENGAN MINAT MEMBUKA USAHA BOGA SISWA SMK PENCAWAN MEDAN
}

\author{
Regina Pertiwi dan Nuwairi Hilda \\ (Pengusaha Rumah Makan dan Dosen Prodi Tata Boga)
}

\begin{abstract}
ABSTRAK
Penelitian ini bertujuan untuk mengetahui : (1) Intensitas Informasi Kebogaan Melalui Media Cetak (2) Minat Membuka Usaha Boga (3) Hubungan Intensitas Informasi Kebogaan Melalui Media Cetak dengan Minat Membuka Usaha Boga. Lokasi penelitian di SMK Pencawan Medan dan jumlah responden 37 orang. Teknik pengambilan sampel dengan menggunakan teknik total sampling yaitu mengambil semua populasi sebagai sampel.Data variabel Intensitas Informasi Kebogaan Melalui Media Cetak siswa di jaring dengan menggunakan angket, dan Minat Membuka Usaha Boga Siswa di jaring dengan menggunakan angket.Hasil uji kecenderungan dari variabel Intensitas Informasi Kebogaan Melalui Media Cetak siswa sebesar 67,6\% berada dalam kategori cenderung cukup, sedangkan untuk variabel Minat Membuka Usaha Boga Siswa sebesar $51,4 \%$ berada dalam kategori cenderung cukup. Serta penelitian ini menunjukkan bahwa terdapat Hubungan yang positif antara Intensitas Informasi Kebogaan Melalui Media Cetak dengan Minat Membuka Usaha Boga Siswa SMK Pencawan Medan.Hal ini ditunjukan Dengan nilai $r_{x y}$ sebesar 0,546 dan rtabel0,325 pada taraf signifikan 5\%. Dengan demikian hargarxy >rtabel yaitu 0,546>0,325. Sehingga dapat disimpulkan hipotesis yang di ajukan yaitu terdapat " Hubungan yang Positif antara Intensitas Informasi Kebogaan Melalui Media Cetak dengan Minat Membuka Usaha Boga siswa di SMK Pencawan Medan atau hipotesis penelitian yang diajukan diterima pada taraf signifikansi $\alpha=0,05$.
\end{abstract}

\section{Kata Kunci : Hubungan Intensitas Informasi Kebogaan Melalui Media Cetak, Minat Membuka Usaha Boga}

\section{PENDAHULUAN}

Intensitas Informasi kebogaan melalui media cetak yang sedemikian rupa diharapkan dapatmembangun paradigma masyarakat yang membacanyasehingga dapatmempengaruhi pola pikir, etos dan kefahaman atas suatu peristiwa. Menurut Danim, (2011) Membaca berarti aktivitas melihat dan memahami sesuatu dengan tingkat perhatiantertentu . Dengan membaca media cetak sebagai media visual dengan tingkat perhatiantertentu. Dalam hal yang lebih krusial lagi, Pemberitaan dalam media cetak belum dimanfaatkan secara optimal sehingga para pembaca diharapkan dapat berpartisipasi, bahkan hingga tindakan dan perilaku.

Dengan membaca berita yang di terbitkan di dalam media cetak yang bertema boga, diharapkan siswa dapat mengembangkan dan menerapkan ilmu yangdiperoleh di sekolah sehingga dapat dijadikan inspirasi berkreasi. Dengan pertimbangan bahwa media cetak dapat memberikan informasi-informasi kebogaan dan membantu siswa SMK dalam memperoleh inspirasi untuk berkreasi. Intensitas informasi denganmembaca dapat memberikan pengaruh yang positif pada minat membuka usaha boga.

SMK PENCAWAN adalah sekolah menengah kejuruan bidang Kebogaan, dengan program keahlian Tata Boga.SMK PENCAWAN diajar oleh tenaga pendidik professional danpraktisi Tata Boga berpengalaman di program diklat dan keahlian masing-masing, berlatarbelakang SI dan S2.

Berdasarkan observasi penulis tanggal 5 Oktober 2015, dengan Ibu Iren sebagai program keahlian Tata Boga di SMK Pencawan Medan diperoleh data siswa Tata Boga tahun 2011 dari 35 siswa, 28,36\% diantaranya melanjutkan pendidikan ke 
perguruan tinggi, 52,11\% siswa bekerja, dan $19.53 \%$ siswa tidak diketahui. Tahun 2012 dari 38 siswa, $32.84 \%$ diantaranya melanjutkan pendidikan ke perguruan tinggi, $55.63 \%$ siswa bekerja, dan $11.53 \%$ siswa tidak diketahui. Berdasarkan hasil observasi di atas sebagian besar tamatan SMK di jurusan Tata Boga lebih memilih mencari pekerjaan dari pada menciptakan lapangan pekerjaan.Jadi dari hal tersebut, segala kekurangan yang ada harus dibenahi agar dapat meningkatkan intensitas informasi kebogaan, hasil belajar dan minat membuka usaha.

Berdasarkan masalah di atas, peneliti tertarik untuk melakukan penelitian tentang hubungan intensitas informasi kebogaan melalui media cetak dengan minat membuka usaha boga pada siswa kelas XII SMK PENCAWAN Medan Tahun Ajaran 2015/2016. Sesuai dengan indentifikasi, pembatasan masalahdan rumusan masalah diatas maka tujuan penelitian ini yakni untuk mengetahui:

1. Untuk mengetahui intensitas informasi kebogaan melalui media cetak siswa kelas XII SMK Pencawan Medan

2. Untuk mengetahui minat mebuka usaha boga siswa kelas XII SMK PENCAWAN Medan.

3. Untuk mengetahui hubungan intensitas informasi kebogaan melalui media cetak dengan minat membuka usaha boga.

\section{KAJIAN TEORITIS}

Menurut bahasa, intensitas berasal dari bahasa Inggris yaitu Intensity yang berarti: kemampuan, kekuatan, gigih atau kehebatan. Intensitas juga diartikan sebagai kata sifat dalam kamus ilmiah popular dengan kata intensif yang berarti : (secara) sunguh-sungguh, tekun, giat, sedangkan pengertian intensity (intensitas) menurut kamus Psikologi ialah kekuatan yang mendukung suatu pendapat atau suatu sikap. Sedangkan kata Intensitas adalah keadaan (tingkatan, ukuran) intensnya (kuat dan hebat) dan sebagainya. Dalam Corsini (2002), intensitas didefinisikan sebagai: "The Quantitative Value Of Stimulus" (Depdikbud :2001) Berdasarkan pengertian diatas, intensitas dapat diartikan sebagai seberapa besar respon individu atas suatu stimulus yang diberikan kepadanya ataupun seberapa sering melakukan suatu tingkah laku. Dalam penelitian ini, istilah intensitas diartikan sebagai seberapa sering siswa mendapatkan informasi kebogaan.

Media adalah segala sesuatu yang dapat digunakan untuk menyalurkan pesan dari pengirim ke penerima sehingga dapat merangsang pikiran, perasaan, perhatian, dan minat serta perhatian siswa. Media cetak merupakan suatu media yang bersifat statis dan mengutamakan pesan pesan visual. Media ini terdiri dari lembaran kertas dengan sejumlah kata , gambar atau foto dengan tata warna dan halaman putih. Media cetak merupakan dokumen atas segala dikatakan orang lain dan rekaman peristiwa yang ditangkap oleh jurnalis yang diubah dalam bentuk kata kata , gambar, foto dan sebagainya. Dalam pengertian ini media cetak yang dipakai untuk memasang iklan adalah majalah dan buku resep.

Menurut Shaleh (2004) minat adalah suatu kecenderungan untuk memberikan perhatian dan bertindak terhadap orang, aktivitas atau situasi yang menjadi objek dari minat tersebut dengan disertai perasaan senang. Kesadaran seseorang yang tertarik dan senang pada suatu usaha akan nampak dalam kegiatan mempelajari, memahami, dan berkecimpung dalam usaha itu. Aktivitas atau kegiatan yang dilandasi dengan minat kemungkinan besar akan berhasil, karena dilakukan dengan rasa senang dan tanpa paksaan.

Kata usaha dapat diartikan sebagai keseluruhan kegiatan yang dilakukan yang dijalankan orang orang atau badansecara teratur dan terus menerus, yaitu berupa kegiatan yang mengadakan barang atau jasa maupun fasilitas lain untuk dijual, dipertukarkan atau disewagunakan dengan tujuan memperoleh keuntungan yang optimal.

Membuka suatu usaha, tidak terkecuali usaha boga tentu ada sesuatu yang ingin dicapai, membuka suatu usaha dan usaha itu berhasil dalam arti menghasilkanprofit dan berkembang sudah tentu menjadi tujuan yang diharapkan. 
Namun dengan demikian tidak semudah itu untuk mendapatkannya, banyak halyang harus dilakukan bahkan dengan berbagai pengorbanan baik moral maupun material. Berbagai prinsip perlu dilakukan, mulai dari perencanaan sampai pada pengendalian, atau dengan kata lain langkah langkah manajemen usaha, baru dipersiapkan dengan sungguhsungguh. Untuk menyelenggarakan suatu usaha makanan, baik yang bersifat komersial maupun non komersil.

Pengelolaan usaha boga adalah usaha yang menawarkan produk nyata di bidang makanan dan minuman yang ditawarkan kepada pasar dengan keuntungan yang sebesar besarnya. Samsir (2011), pengelolaan adalah cara untuk menangani pelaksanaansuatu kegiatan yang terprogram dengan baik melalui kerja sama dengan baik, yang dimaksud terprogram dengan baik meliputi : (1) dimulai dari perencanaan, (2) pelaksanaan rencana, (3) melaksanakan pengendalian terhadap pelaksanaan rencana agar tidak terjadi penyimpangan penyimpangan.

\section{METODOLOGI PENELITIAN}

Desain penelitian yang digunakan adalah desain penelitian korelasional yang bertujuan untuk menemukan hubungan 2 variabel atau lebih (Syaodih, 2010).Penelitian ini dilaksanakan di kelas XIIProgram Keahlian Tata Boga SMK PENCAWANMedan yang beralamatJln. Bunga Cole No. 50 Medan Tuntungan, Kota Medan.

Populasi dalam penelitian ini adalah seluruh siswa kelas XII SMK PANCAWAN Medan yang terdiri dari 1 kelas dengan kompetensi keahlian Jasa Boga dengan jumlah siswa seluruhnya adalah 37 siswa.

Sampel adalah sebagian atau wakil populasi yang diteliti, apabila subjek kurang dari 100 orang, lebih baik di ambil semua sehingga penelitiannya merupakan penelitian populasi (Arikunto, 2006).Berdasarkan pendapat tersebut sampel dalam penelitian ini adalah seluruh siswa kelas XII SMK PENCAWAN Medan dengan jumlah 37 orang, sehingga seluruh populasi dijadikan sampel atau sampel total.
Uji coba instrumen penelitian dilakukan untuk mendapatkan alat ukur yang benar-benar akurat agar kesimpulan yang diperoleh sesuai dengan kenyataan kondisi lingkungan. Uji coba instrument dilaksanakan pada siswa kelas XII SMK Panca Budi 2 Medan, siswa sebanyak 30 orang.Uji coba yang digunakan terhadap instrumen penelitian adalah uji coba validitas dan uji coba realibilitas (Arikunto, 2010).

\section{HASIL DAN PEMBAHASAN}

\section{Hasil Penelitian}

Berdasarkan data yang diperoleh dari hasil penelitian dengan jumlah responden 37 orang, skor tertinggi $=160$ dan skor terendah $=118$ dengan rata-rata $(\mathrm{M})=141,97$ dan standar deviasi $(\mathrm{SD})=10,91$. Distribusi frekuensi skor variabel intensitas informasi kebogaan melalui media cetak terdiri dari 6 kelompok, menunjukkan bahwa intensitas informasi kebogaan melaluimedia cetak yang berada pada interval kelas 139 s/d 145 dan 146 s/d 152 dengan frekuensi 24,3\%, pada interval kelas 132 s/d 138 dan 153 s/d 160 dengan frekuensi $16,2 \%$, dan pada interval kelas $118 \mathrm{~s} / \mathrm{d} 124$ dengan frekuensi 13,5\%.

Berdasarkan data hasil penelitian dengan jumlah responden 37 orang, skor tertinggi $=160$ dan skor terendah $=105$ dengan rata-rata $(M)=135,45$ dan standar deviasi $(\mathrm{SD})=13,95$. Distribusi frekuensi skor variabel minat membuka usaha boga terdiri dari 6 (enam) kelompok, menunjukkan bahwa minat membuka usaha boga yang berada pada interval kelas 132 - 140 dengan frekuensi $27 \%$, pada interval kelas 123 - 131 dengan frekuensi $21,6 \%$, pada interval kelas 150-160 dengan frekuensi $19 \%$, pada interval kelas 141-149 dengan frekuensi $16,2 \%$, pada interval kelas 114-122 dengan frekuensi $10,8 \%$, dan pada interval kelas 105-113 dengan frekuensi 5,4\%.

Untuk mengidentifikasi kelas kecenderungan intensitas informasi kebogaan melalui media cetak yang dikumpulkan dengan angket dengan jumlah soal 46 item dan skor tertinggi 4 dan terendah 1, rata-rata mean ideal $(\mathrm{Mi})=115$ dan standar deviasi ideal (Sdi) sebesar 23. Bila digunakan norma kategori maka secara terperinci intensitas informasi kebogaan melalui mediadapat 
dilihat kategori intensitas informasi kebogaan melalui media cetak $67,6 \%$ cukup, dan $32,4 \%$ tinggi. Dari indikator intensitas informasi kebogaan melalui media cetak dapat dilihat tingkat perhatian siswa pada media cetak dan informasi informasi yang didapatkan siswa dengan membaca media cetak. Dengan demikian dapat disimpulkan bahwa intensitas informasi kebogaan melalui media cetak siswa kelas XII SMK Pencawan Medan tergolong dalam kategori cukup $(67,6 \%)$.

Untuk mengidentifikasi kelas kecenderungan minat membuka usaha boga yang dikumpulkan dengan angket dengan jumlah soal 42 item dan skor tertinggi 4 dan terendah 1, maka diperoleh rata-rata mean ideal (Mi) 105 dan standard deviasi ideal $($ Sdi $)=21$. Bila digunakan kategori minat membuka usaha boga maka secara terperinci dapat dilihatkategori minat membuka usaha boga 48,6 \% tinggi, 51,4\% cukup, katagori kurang dan kategori rendah tidak ada. Dari indikator minat membuka usaha boga ternyata siswa memiliki rasa percaya diri, dapat mengambil resiko, kreatif dan inovatif, disiplin dan kerja keras, berorientasi ke masa depan, memiliki rasa ingin tahu, jujur dan mandiri. Dengan demikian dapat disimpulkan bahwa minat membuka usaha boga siswa kelas XII SMK Pencawan Medan tergolong dalam kategori cukup $(51,4 \%)$.

Distribusi skor data variabel penelitian harus memenuhi syarat normalitas.Uji normalitas bertujuan untuk mengetahui normal tidaknya data variabel penelitian.Pengujian ini dilakukan dengan menggunakan uji Liliefors. Data untuk setiap variabel dikatakan normal apabila $\chi^{2}$ hitung $<\chi_{\text {tabel }}^{2}$, pada taraf signifikansi $5 \%$ terhadap hasil angket.

Diperoleh harga $\mathrm{L}_{\text {hitung }}=0,0378$. Kemudian harga tersebut dibandingkan dengan harga $\mathrm{L}_{\text {tabel }}$ untuk uji Liliefous dengan taraf signifikan $\alpha=0,05$ dan $\mathrm{N}=37$, didapat:

nilai $\operatorname{Ltab}=\frac{0,886}{\sqrt{n}}=\frac{0,886}{\sqrt{37}}=0,145$

Setelah dibandingkan didapat $\mathrm{L}_{\mathrm{hit}}<$ $\mathrm{L}_{\text {tab }} \quad(0,0378<0,145) \quad$ sehingga dapat disimpulkan bahwa data intensitas informasi kebogaan melalui media cetak berdistribusi normal. Diperoleh harga $\mathrm{L}_{\text {hitung }}=0,0432$. Kemudian harga tersebut dibandingkan dengan harga $\mathrm{L}_{\text {tabel }}$ untuk uji Liliefous dengan taraf signifikan $\alpha=0,05$ dan $\mathrm{N}=37$, didapat:

nilai $\operatorname{Ltab}=\frac{0,886}{\sqrt{n}}=\frac{0,886}{\sqrt{37}}=0,145$

Setelah dibandingkan didapat $\mathrm{L}_{\mathrm{hit}}<$ $\mathrm{L}_{\text {tab }} \quad(0,0432<0,145) \quad$ sehingga dapat disimpulkan bahwa data minat membuka usaha boga berdistribusi normal

Uji linieritas dilakukan untuk mengetahui linier atau tidaknya hubungan variabel bebas dan variabel terikat yang merupakan syarat untuk menggunakan analisis regresi. Dalam penelitian ini ada satu variabel bebas yang diduga memiliki hubungan dengan variabel terikat sehingga ada satu persamaan regresi yang perlu diuji kelinierannya. Perhitungan uji linieritas dapat dilihat pada lampiran 13. Pada tabel 11 disajikan ringkasan analisis varians (ANAVA) yang menguji kelinieran minat membuka usaha boga (Y) atas intensitas informasi kebogaan melalui media cetak (X).Dapat dilihat bahwa uji linieritas diperoleh $F_{\text {hitung }}<F_{\text {tabel }}(-0,341<2,913)$, sehingga persamaan $\mathrm{Y}$ atas $\mathrm{X}$ linier. Dengan demikian dapat disimpulkan persamaan regresi $\widetilde{Y}=36,36+0,69 \mathrm{X}$ mempunyai hubungan yang linier pada taraf signifikan $5 \%$.

Untuk melihat korelasi antara variabel intensitasinformasi kebogaan melalui media cetak dengan minat membuka usaha boga digunakan rumus korelasi product moment. Hasil analisis product moment, diperoleh korelasi antara intensitas informasi kebogaan melalui media cetak dengan minat membuka usaha boga dengan nilai $r_{x y}=0,546$.

Hasil analisis perhitungan korelasi $r_{x y}$, $\mathrm{r}_{\text {hitung }}$ sebesar 0,546 dengan jumlah responden 37 orang dan $r_{\text {tabel }} 0,325$ pada taraf signifikan $5 \%$, dengan demikian harga $r_{\text {hitung }}>r_{\text {tabel }}$ $(0,546>0,325)$ maka hipotesis yang menyatakan terdapat hubungan intensitas 
informasi kebogaan melalui media cetak dengan minat membuka usaha boga dapat diterima.

\section{Pembahasan Penelitian}

Berdasarkan hasil yang diperoleh dari analisis data dan setelah diadakan pengujianpengujian, maka sesuai uji kecenderungan ditemukan hasil penelitian bahwa intensitas informasi kebogaan melalui media cetaksiswa kelas XII SMK Pencawan Medantergolong cukup. Hal ini terlihat dari 37 responden yang tergolong dalm katagori tinggi 12 orang $(32,4 \%)$ dan katagori cukup 25 orang $(67,6 \%)$. Intensitas informasi kebogaan melalui media cetak masih tergolong cukup dikarenakan siswa kurang berkeinginan untuk membaca media cetak , seperti buku dan majalah boga, Hal ini dikarenakan informasi yang didapatkan siswa tidak hanya diperoleh dari media cetak melainkan media elektronik seperti Televisi dan Hanphone. Sedangkan minat membuka usaha boga siswa kelas XII SMK Pencawan Medan dikategorikan cenderung cukup. Hal ini terlihat dari 37 responden yang tergolong tinggi 18 orang $(48,6 \%)$ dan katagori cukup 19 orang $(51,4 \%)$. Minat membuka usaha boga siswa masih tergolong cukup dikarenakan minimnya pengetahuan, kurang percaya diri, dan tidak berani mengambil resiko. Maka, untuk meningkatkan minat membuka usaha siswa perlu ditingkatkan pengetahuan boga dengan membaca buku atau majalah. Dan didukung penuh dalam pengambilan resiko karena wirausaha harus memiliki pertimbangan dan perhitungan matang untuk mengambil resiko.

Dari hasil analisis korelasi product moment ditemukan harga koefisien hubungan intensitas informasi kebogaan melalui media cetak (X) dengan minat membuka usaha boga (Y) siswa kelas XII SMK Pencawan Medan $r_{x y}$ sebesar 0,546 dan setelah diuji keberartian ternyata pada taraf signifikan 5\% dengan $\mathrm{n}=37$ sebesar 0,325 . Hal ini berarti bahwa hipotesis yang berbunyi "terdapat hubungan yang positif dan signifikan antara intensitas informasi kebogaan melalui media cetak dengan minat membuka usaha boga siswa kelas XII SMK Pencawan Medan" teruji kebenarannya.

\section{KESIMPULAN}

Berdasarkan hasil penelitian yang telah diuraikan, maka dapat disimpulkan halhal sebagai berikut : (1) Intensitas Informasi Kebogaan Melalui Media Cetak pada siswa kelas XII program keahlian tata boga SMK Pencawan Medan berada pada kategori cukup $(67,6 \%)$ dengan rata-rata hitung sebesar 141,97 dan standar deviasi 10,91. Hal ini disesuaikan Dari indikator intensitas informasi kebogaan melalui media cetak dapat dilihat tingkat perhatian siswa pada media cetak dan informasi informasi yang didapatkan siswa dengan membaca media cetak, (2) Minat membuka usaha boga pada siswa kelas XII program keahlian tata boga SMK Pencawan Medan berada pada kategori cukup $(51,4 \%)$ dengan rata-rata hitung sebesar 135,45 dan standar deviasi 13,95. Hal ini dilihat dari indikator minat membuka usaha boga ternyata siswa memiliki rasa percaya diri, dapat mengambil resiko, kreatif dan inovatif, disiplin dan kerja keras, berorientasi ke masa depan, memiliki rasa ingin tahu, jujur dan mandiri, dan (3) Terdapat hubungan yang signifikan antara intensitas informasi kebogaan melalui media cetak dengan minat membuka usaha boga siswa kelas XII program keahlian tata boga SMK Pencawan Medan dengan koefisien korelasi $r_{\mathrm{xy}}=0,546$ dan $r_{\text {tabel }}=0,325$ pada taraf signifikan $5 \%$.

\section{DAFTAR PUSTAKA}

Aminah , (2000). Kewirausahaan.PT Raja Grafindo Perkasa. Jakarta.

Arikunto, Suharsimi. (2011). Prosedur Penelitian Suatu Pendekatan Praktek.Jakarta : PT. Rineka Cipta.

Azhar Arsyad, M.A. 2011. Media Pembelajaran.Jakarta : Rajawali Pers.

Corsini, (2002). The Quantitative Value Of Stimulus. PT. Raja Grafindo Persada.

Depdikbud.2001. Kamus Besar Bahasa Indonesia.Jakarta : Balai Pustaka.

Edward. 2004. Belajar Dan Pembelajaran. Jakarta : Rineka Cipta. 
Google, http:// image.google.com//. Yang diakses pada tanggal 13 maret 2015.Jam : 09.00 WIB.

Nazir, Moh. 2003. Metode Penelitian. Penerbit : Ghalia Indonesia Anggota IKAPI.

Nizar, Mulyatni, dkk. 2012. Pedoman Pratikum Ilmu Pangan Dasar. Padang.

Sadirman. A.M. 2007.Interaksi Dan Motivasi Belajar Mengajar. Jakarta: PT. Raja Grafindo Persada.

Shaleh, (2004). Minat Wirausaha Tersedia pada: //ilmuakutansi.web.id/pengertiankewirausahaan-menurut-ahli/ $\quad d i$ akses20 maret 2015)
Suryana, AS. 2007. Eksitensial untuk Wirausaha Masa Depan. Makassar : Salemba Empat.

Suryana. 2007. Kewirausahaan. Jakarta : Salemba Empat.

Syaodih, Nana. 2010. Metode Penelitian Pendidikan. Bandung : PT. Remaja Rosdakarya.

Yuyun Wirasasmita. 2004. Kewirausahaan :Buku Pegangan Jatinangor : UPTPenerbit IKOPIN. 